\title{
魚肉ソーセージのソルビン酸による保存効果の再検討
}

\author{
(昭和 50 年 9 月 16 日受理)
}

$\begin{array}{lll}\text { 和田 } & \text { 俊*1 } & \text { 野中順三九 } \\ \text { 小1 } & \text { 小泉千 秋*1 } \\ \text { 小沼博 隆*2 } & \text { 鈴木 }\end{array}$

\section{The Preservative Effects of Sorbic Acid for Fish Sausage}

\author{
Shun WADA*1, Junsaku NoNAKA*1, Chiaki KoIZUMI*1 \\ Hirotaka KoNUMA and Akira SUZUKI \\ (*1)Tokyo University of Fisheries: $4-5-7$ Konan, Minato-ku, Tokyo; \\ *2National Institute of Hygienic Science: 18-1, Kamiyoga, \\ 1-chome, Setagaya-ku, Tokyo)
}

\begin{abstract}
Sorbic acid has been used as antiseptic for fish sausage, since the use of AF-2[2-(furyl) -3-(5-nitro-2-furyl) acrylamide], which had been one of the effective preservatives for fish sausage, was prohibited in July of 1974. Therefore, the preservative effects of sorbic acid for fish sausage was reinvestigated in connection with $\mathrm{pH}$ value and storage temperature of the sausage. The results obtained are as follows.

1) At storage temperature of $30^{\circ} \mathrm{C}$, the shelf life of fish sausage with the $\mathrm{pH}$ values of lower than 5.9 was about one week. Additions of sorbic acid to the sausages at the level of 0.1 and $0.2 \%$ prolonged their shelf lives for one and two weeks respectively.

2) At storage temperature of $10^{\circ} \mathrm{C}$, the sausages with about $6.2 \mathrm{of} \mathrm{pH}$ did not show any sign of spoilage for the test period of 7 weeks without regard to the addition of sorbic acid. The same results were obtained at the elevated storage temperature of $15^{\circ} \mathrm{C}$.

3) From these results, it was presumed that fish sausages added at the level of $0.2 \%$ of sorbic acid could be preserved for at least two months at about $10^{\circ} \mathrm{C}$, if the $\mathrm{pH}$ is adiusted to the suitable $\mathrm{pH}$ range in which sorbic acid shows effective bacteriostatic action.
\end{abstract}

(Received September 16, 1975)

魚肉ハム・ソーセージの保存性が, 殺菌料 2-(2-フリ ル)-3-(5-ニトロ-2-フリル) アクリルアミド $\left(\mathrm{AF}_{2}\right)$ に負 らところが大であったことは周知のとおりであるが，こ の殺菌料は昭和 49 年 7 月以降使用が禁止された。 また, この措置に伴って, 魚肉ハム・ソーセージは, その殺菌 加熱処理条件，水分活性および $\mathrm{pH}$ 值の調節の有無によ り常温流通製品と，低温流通製品とに区分されることに なった. このため，魚肉ハム・ソーセージに添加できる 防腐剂はソルビン酸のみとなり, 魚肉ソーセージに対す るソルビン酸の保存効果を再検討する必要が生じた.

従来行われた防腐剂としてのソルビン酸についての研 究には, 市販の魚肉ソーセージなどから分離した細菌や

*1 東京水産大学: 東京都港区港南 4-5-7

*2 国立衛生試験所：東京都世田谷区上用賀 1-18-1

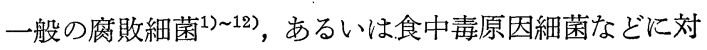
する発育・発芽阻止効果に関するものが多く, 直接, 魚 肉ハム・ソーセージに対する保存効果を検討したのもは

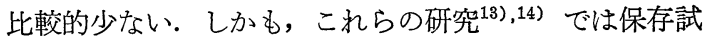
験は $37^{\circ}$ か, あるいは室温で行われたものが多く, 製品 の保存性に及ぼす保存温度の影響, 特に低温保存につい て調ベたものは少ない.

本研究では, 魚肉ソーセージに対するソルビン酸の保 存効果を再検討するために, 常温流通を目標とした製品 の $30^{\circ}$ 貯蔵に怙ける保存性, および低温流通が規定され ている製品の $10^{\circ}$ あるいは $15^{\circ}$ 貯蔵に拈ける保存性と細 菌数の変動について検討した.

実験

1）供試魚肉ソーセージ：魚肉ハム・ソーセージ協会 
を通じ林兼食品工業(株)の協力を得て作成したもので, 外径 $3 \mathrm{~cm}, 120 \mathrm{~g}$ 詰め, 原料拉よび配合は, 市場に流 通している製品と同じである. 水分活性は特に調整しな かった. 殺菌加熱条件は， $88 \sim 90^{\circ} ， 50$ 分間とし，ヶー シングは, 塩化ビニリデン系サランを使用した，常温流 通供試品の製造值後の $\mathrm{pH}$ はすべて 5.9 以下，すなわ ち, ソルビン酸 $0.2 \%$ 添加の供試品では $\mathrm{pH} 5.82$, ソル ビン酸 $0.1 \%$ 添加のものは $\mathrm{pH} 5.80$ に調整したものを それぞれ 20 本ずつ作成した。 また，低温流通品としては pH 6 付近のものを 40 本ずつ作成した. 試験に際して は, 各試験群より 1 本ずつ抜きとり, その半分を化学検 查に, 残り半分を細菌数測定に用いた。

2) 貯蔵温度：低温流通供試品は 10 於よび $15^{\circ}$ そ，ま た常温流通を目標にした供試品は $30^{\circ}$ とそれぞれ貯蔵し， 1 週間ごとに供試した。

3) $\mathrm{pH}$ の測定：乳錰中で試料に10倍量の蒸留水を加

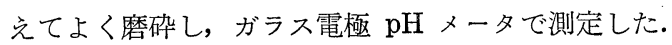

4) 官能検査：臭気・味・弾力などを中心に研究室員 によって行われた。

5) 揮発性塩基窒素（以下 VBN と略称する）および トリメチルアミン (以下 TMA-N と略称する)：5\%三 塩化酷酸抽出液について Conway の微量拡散法により 測定した。

6) ソルビン酸の測定: 梄府ら ${ }^{16)}$ のガスクロマトグラ フィーを参照し, 島津製 GC-4BM 型を用い, 次の条件 で分析した；液相： $5 \%$ diethylenglycol succinate (DEGS) $+1 \%$ リン酸, カラム: $4 \mathrm{~mm} \times 2 \mathrm{~m}$ ガラスカラ ム, カラム温度: $170^{\circ}$, 検出器: 水素炎イオン化検出器.

7) ゼリー強度の測定：岡田式ゼリ一強度試験器で測 定した.

\section{8) 細菌数の測定}

i) 好気性菌：食品衛生検査指針（I）の生菌数測定法 に準拠して作成した試料について, 生菌数測定用標準寒 天培地を用いた。培養温度はそれぞれの供試品が貯蔵さ れていた温度と同一とし， $30^{\circ}$ 試験群については $30^{\circ} 48$ 時間, $15^{\circ}$ 試験群については $15^{\circ} 7$ 日間, $10^{\circ}$ 試験群に ついては $10^{\circ} 10$ 日間培養により測定した。

ii) 嫌気性菌: チオグリコール酸塩 (TGC) 培地を用 い, 大腸菌群の MPN 測定法に準拠し, 婙気性菌の確 認は次のように行った。 まず，菌の発育が認められた試 験管から 1 白金耳嫌気性菌用平板寒天培地である GAM 寒天培地「ニッサン」(GAM 培地) に画線塗抹して嫌 気培養 $[$ (gas pack system) $(\mathrm{BBL})]$ した. 菌集落の発 生が認められたものを, さらに嫌気・好気培養し, 嫌気 培養で発育し, 好気培養の結果発育を示さないものを嫌 気性菌とした.な拈, 供試品の一定量を直接 GAM 培地 平板にコンラージ棒で塗抹し, 発生した集落を数え, 同 時に釣菌，分離し前述の方法にならって嫌気性菌である ことを確認した.

\section{結果および考察}

\section{1）常温流通供試品の $30^{\circ}$ における保存性}

供試品の $\mathrm{pH}, \mathrm{VBN}, \mathrm{TMA}-\mathrm{N}$, ゼリ一強度, 細菌数な ぞの変化, 官能検査の判定結果およびソルビン酸残存量 を Table 1 に示した. 総合判定に当たってはたとえ官 能検査に拈いて正常と認められたものでも, 細菌数の増 加の認められたものはその前の週で, また逆に細菌数の 増加がそれほど著しくなくても, 官能検査で異常が認め られたものは, やはりその前の週で, それぞれ正常の限 界とした.

VBN 抢よび TMA-N は，いずれの試験群の場合で も試験期間を通じてわずかずつ漸増し，官能検査で異常 が認められたり，また細菌数が増加して正常な限界を過 ぎた時点でも，顕著な增加を示さなかった， $\mathrm{pH}$ もこれ と同様な傾向を示した.

細菌数は, $0.2 \%$ ソルビン酸添加群では, 5 週間後ま では顕著な増加はなかったが，官能検査で 4 週間後に異 常が認められた. $0.1 \%$ ソルビン酸添加群では官能検査 で 3 週間までは異常は認められなかったが，この時点で 菌数は $20 \times 10^{5}$ とかなり増加していた. 以上のことから 総合的に判定すると, 製造直後と变わりがなく正常と判 定されたのは， $0.2 \%$ ソルビン酸添加群では 3 週間後ま でまた $0.1 \%$ ソルビン酸添加群では 2 週間後までとな り, ソルビン酸添加量の相違による保存性の差が認めら れた. これに対して対照のソルビン酸無添加品は, 1 週 間後の官能検査の成績は正常であったが, 菌数の增加が すでに著しく, 保存の限界を越光ていると判定された.

なお，ソルビン酸の残存量は試験期間を通じて変化な く, またゼリ一強度にも, 有意な変化は認められなかっ た.

佐藤 ${ }^{1)}$ はソルビン酸による魚肉ソーセージの防腐試験 で，0.2\%のソルビン酸を添加した試料が，夏季室温で, 72時間で変化を来たしたと述べているが，一方，上田 ${ }^{14)}$ は同様な試験で $0.2 \%$ のソルビン酸を添加した魚肉ソー セージは $30^{\circ} て ゙ 16$ 日間以上保存できたと報告し，その 有効性を認めている. 本研究の結果では, ソルビン酸の 添加によってより長期間の保存が可能であった.ここで 供試した常温流通を目標とした製品は, 法律によって規 定されている高温殺菌をした製品ではなく, また水分活 性を下げた製品でもなく，単に $\mathrm{pH}$ 值を低下させただ けの製品である. 岡田ら ${ }^{15}$ が示しているように, ソルビ 酸の有効性は魚肉ソーセージの $\mathrm{pH}$ 值を低下すること により著しく向上するので, 本研究においても $\mathrm{pH}$ 值の 低下が有効に作用したものと思われる. しかし，実用的 な消費サイクルを満たすために必要といわれている 2 か 月以上の保存は不可能であった。

\section{II) 低温流通供試品の保存性}

$10^{\circ}$ と抢ける保存性をみると, Table 2 亿示すように 各試験群とも試験期間の 7 週間までソルビン酸添加の有 


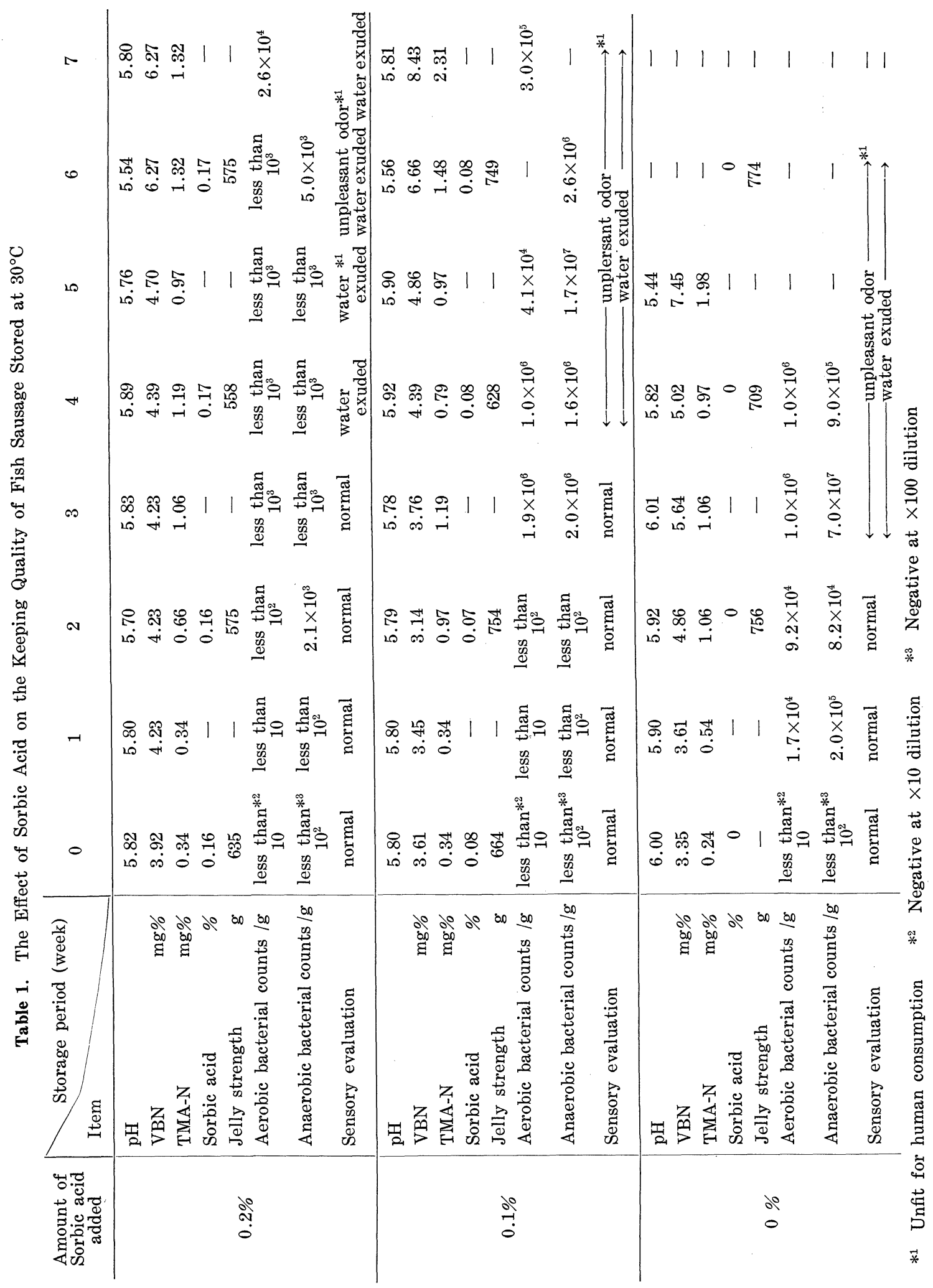




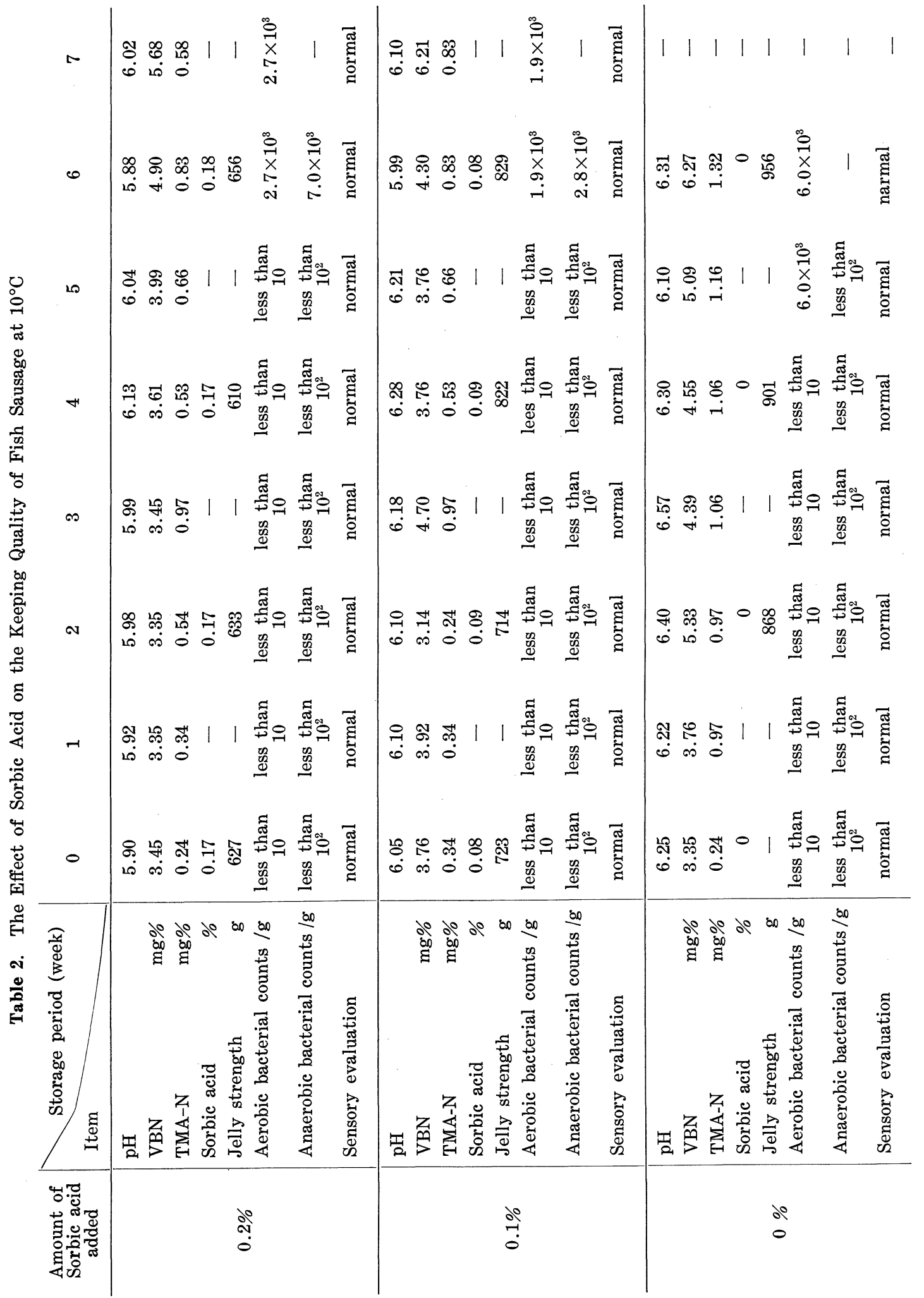




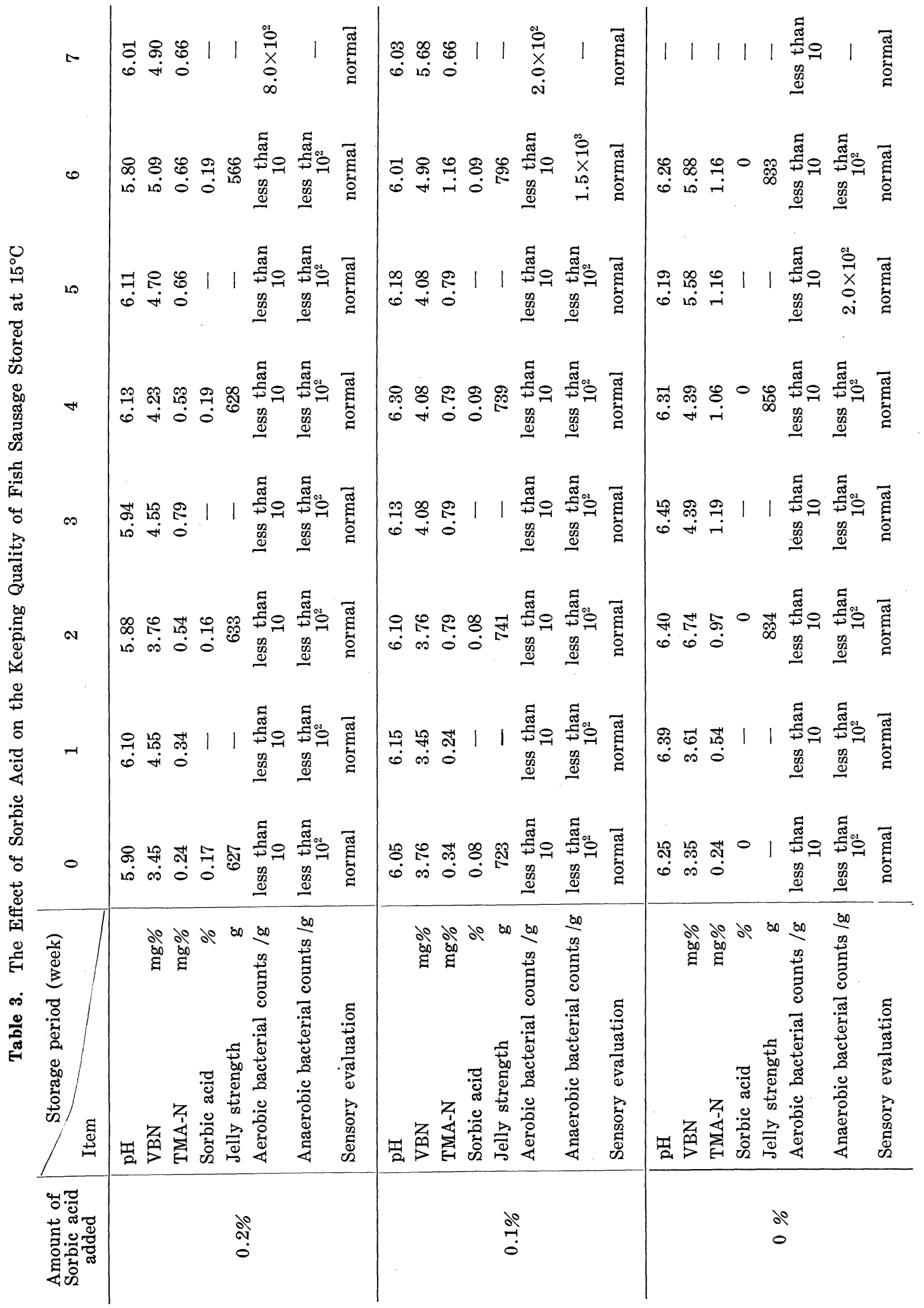


無に関係なく，細菌数の増加，および官能検査における 異常は認められなかった。 また，VBN，TMA-N および $\mathrm{pH}$ なども試験期間中著しい増加は示さなかった。した がって, $10^{\circ}$ 貯蔵では相当長期間の保存が可能と考兄ら れる.

低温流通品は, 法的には $10^{\circ}$ 以下に保存するよう規定 されているが, 流通過程では多少温度が上昇することも あり得ることを想定して $15^{\circ} て ゙$ 保存性を試験した。結果 は Table 3 に示すように, $10^{\circ}$ 保存の場合と同様に 7 週 間以上の保存が可能である.

従来, 魚肉ソーセージの $\mathrm{pH}$ 值は 6.3 付近であったが, 最近では保存性との関係で普通の製品でも $\mathrm{pH}$ 值を低下 させるように工夫されている，低温流通品は，法的には 加熱殺菌条件, 水分活性あるいは $\mathrm{pH}$ 值などの面で, 何 らの規制もされていないが，ここで供試した製品の $\mathrm{pH}$ 值はかなり低かった。これらの製品が， $10^{\circ}$ および $15^{\circ}$ 貯 蔵で 7 週間以上変化なく保存できたのは, 貯蔵温度が低 かったことばかりでなく，pH 值が低かったことにも一 因があると考兄られる. 特に, ソルビン酸を添加した試 料はさらに長期間の貯蔵に耐えるものと思われる.

以上の上5に, ソルビン酸が魚肉ソーセージの保存性 をある程度高めることは， $30^{\circ}$ に抢兴貯蔵試験の結果 から明らかであり,さらに, ソルビン酸が効果的に作用 するような $\mathrm{pH}$ 域に $\mathrm{pH}$ 值を調整した製品を低温貯蔵 すれば, より長期間の保存が可能であると思われる.

\section{要 約}

魚肉ソーセージの保存性に対するソルビン酸の効果を

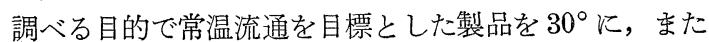
低温流通が規定されている製品を $10^{\circ}$ および $15^{\circ}$ 亿貯蔵 乙， pH 值， VBN, TMA-N, ソルビン酸残存量, ゼり 一強度, 細菌数などの測定预よび官能検査によって品質 を検討し，次のような結果を得た。

1）常温流通を目標とした供試品の $30^{\circ}$ に批ける保存 性はソルビン酸無添加の対照が 1 週間以内であったのに 対し， $0.1 \%$ ソルビン酸拉よび $0.2 \%$ ソルビン酸添加試
料はそれぞれ 2 週間および 3 週間程度であった.

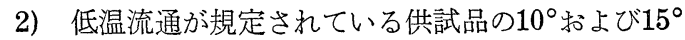
に拁ける保存性は，いずれるソルビン酸添加の有無に関 係なく，7週間以上であった. したがって，ソルビン酸 が有効に作用する $\mathrm{pH}$ 域に魚肉ソーセージの $\mathrm{pH}$ 值を 調整すれば, ソルビン酸の法定許可量以内の使用で, 魚 肉ソーセージを 2 か月程度保存することは可能であるう と推定した.

終わりに，試料の作成に御協力いただいた林兼食品工 業(株)飞感謝する.

文献

1）佐藤正彦：千葉大腐敗研報。7，14 (1954)。

2) 内山 均, 天野慶之: 日水誌. 25, 531 (1959).

3) 興津知明, 河端俊治, 小嶋秩夫：同上, 30,63 (1964).

4）小嶋秩夫，河端俊治，興津知明：同上， 31，934 (1965).

5) 芝崎 勲, 照井鈃造： 酸工. 41，31 (1963).

6) 内山 均, 田龍 仁, 岡田 稔: 日水誌. 32, 436 (1966).

7）谷口忠敬, 徳安 泰子: 長崎大学水産学部研究報 告. 第24号, 89 (1967).

8）高畑京二, 田之上昇, 三宅敬養, 相磯和嘉, 清水 潮，中野栄二：魚肉ソーセージ, No. 146, 30 (1967).

9) Takahata, K., Tanoue, N., Miyake, T., Aiso, K., Shimidu, U., Nakano, E.: 千葉大腐敗研 報. 21，53 (1968).

10）芝崎 勲, 堀江英子：食品工業. 15, 422 (1968).

11) 小沼博隆, 鈴木 昭：食衛誌. 15, 232 (1974).

12) 小沼博隆, 鈴木 昭: 同上, 15, 243 (1974).

13）北野敬雄：ニューフードインダストリー．5，57 (1963).

14）上田 修：魚肉ソーセージ, 90, 34 (1963).

15) 岡田 稔, 武居久弥：日水誌. 31, 628 (1965).

16）樽府直大, 早川順子, 高橋弘明, 石田康雄, 築城 多佳子：食衛誌. 10, 186 (1969). 